\title{
Infection dynamics of Caryophyllaeid tapeworm, Adenoscolex oreini Fotedar, 1958 and impacts of intra-lake pollution gradient on intermediate host (copepods) and health attributes of Schizothorax spp.
}

\author{
U. R. ZARGAR ${ }^{1}$, M. Z. CHISHTI ${ }^{1}$, M. I. RATHER ${ }^{2}$ and S. A. KHANDAY ${ }^{2}$ \\ ${ }^{1}$ Department of Zoology, Central University of Kashmir, Sonwar Campus, Srinagar 190004, India \\ ${ }^{2}$ P.G. Department of Environmental Sciences, University of Kashmir, Srinagar 190006, India
}

(Received 28 November 2016; revised 4 April 2017; accepted 15 April 2017)

\begin{abstract}
SUMMARY
This study is an attempt to unravel the infection pattern of the Caryophyllaeid tapeworm, Adenoscolex oreini and its association with water quality, planktonic copepods and health traits of fish in a highly stressed lake. Prevalence differed significantly $(P<0.05)$ among different fish species with highest infection recorded in Schizothorax niger $(\%=36 \cdot 74)$ compared to Schizothorax esocinus $(\%=15 \cdot 7)$. Within-lake trophic gradient affected the infection pattern as prevalence of $A$. oreini was significantly higher $(44 \cdot 62 \%, P=0 \cdot 0001)$ at hypereutrophic site as compared to least eutrophic site $(8 \cdot 01 \%)$. The data suggest that spatial variation in the intensity of $A$. oreini corresponded to the variation in the abundance of planktonic copepods. The density of Cyclops scutifer was positively correlated with the prevalence of tapeworm. Results indicate that the health condition, which was reflected by condition factor and gonadosomatic index, was lower in parasitized fish, and there seems to be synergistic effect of eutrophication and parasitism on fish health. Linear regression coefficients showed that the health indices were significantly $(P<0.05)$ predicted by infection intensity. It is concluded from the results that within-lake pollution gradient affects the infection pattern, density of intermediate host and health attributes of fish, and therefore these finding will lead us to elucidate the predictors responsible for decline of health of fish in highly stressed water bodies.
\end{abstract}

Key words: Adenoscolex oreini, infection pattern, Cyclops scutifer, planktonic copepods, eutrophication, health traits.

\section{INTRODUCTION}

There is a consensus among ecologists and environmental researchers that stringent management measures are needed in order to combat environmental degradation, which includes pollution, habitat fragmentation, climate change and spread of disease (Siddig et al. 2016). Among various management procedures, biomonitoring has been suggested as the best procedure for the assessment of environmental condition at small or at the large scale (Spellerberg, 2005; Siddig et al. 2016). Although different biological organisms have been utilized for the biomonitoring purpose, parasite-host systems have emerged as the new indicator system from last three decades and various environmental parasitologists have used them for impact assessment studies. The main focus of using parasite-host sentinel system has been to evaluate infection dynamics of parasites, alteration in diversity and accumulation capability in response to various stressors. For example, Palm (2011) successfully showed how parasite diversity of tropical grouper (Epinephelus fuscoguttatus) can be used as an indicator of

* Corresponding author: Department of Zoology, Central University of Kashmir, Sonwar Campus, Srinagar 190004, India. E-mail: uzssummer2@gmail.com environmental change in Indonesian waters, whereas Rückert et al. (2009) showed how parasite descriptors can be used to reflect environmental condition in Segara Anakan lagoon (Indonesia).

The interaction between different environmental pollutants and host-parasite system has been a central theme of research in last three decades, and there has been a great progress in understanding various aspects of host-parasite interaction in relation to various stresses. There are various possibilities when host, parasite and stressful environment interact with each other. The parasitism may show increase or decrease depending upon the type of stressor involved in the interaction. For example, parasitic infections upsurge under eutrophic water conditions, whereas parasitism might decrease under highly eutrophic condition, thus indicating the deleterious effect of enhanced eutrophication on the parasite infection (Zargar et al. 2012c). Generally, past research has shown mixed response against various stressors, with some showing positive effect, while others showing negative response. However, eutrophications (nutrient enrichment of water bodies) are considered to be suitable for the transmission and progression of many fish parasites (Blanar et al. 2009; Zargar et al. 2012b). Another important aspect is that the alteration in parasitic

Parasitology Open (2017), Vol. 3, e6; page 1 of 13. (C) Cambridge University Press 2017. This is an Open Access article, distributed under the terms of the Creative Commons Attribution licence (http://creativecommons.org/licenses/by/4.0/), which permits unrestricted re-use, distribution, and reproduction in any medium, provided the original work is properly cited. 
infection under stressful condition can either reduce health of fish or may have other negative effects. For example, the increased level of parasitism may further reduce the health condition of fish, which has been already weakened by contamination exposure. It is therefore important to understand such interaction associated with health status of endangered species (Morley et al. 2010). In addition, there is need to understand the overarching factors influencing parasite-host interactions under highly stressed aquatic ecosystem.

Among fish cestodes, Caryophyllaeid tapeworms have been central of focus due to their simple seasonality (Williams and Jones, 1994) and their potential to act as pathogen of both farmed and wild fish (Kennedy, 1994; Oros et al. 2004). Furthermore, investigations on the phylogeographical and molecular aspects of Caryophyllaeid cestode (Atractolytocestus huronensis) have been suggested to be necessary for the elucidation of invasive nature and other speciation mechanisms. However, very few attempts have been made to ascertain the relationship between Caryophyllaeid tapeworm and health condition of fish under highly stressed aquatic ecosystems. It is pertinent to mention that there is scanty literature where researchers have attempted to assess the within-lake variation of parasitic infection. However, Karvonen et al. (2005) attempted to analyse the spatial and temporal variation in factors affecting the parasite fauna of perch (Perca fluviatilis) at different locations of the same lake and observed that the geographical distance within the same lake affects the similarity of parasites. The intra-lake variation in physicochemical features has been found to have an influence on the infection level of monogenean gill parasite in highly stressed lake (Zargar et al. 2012c). In addition, seasonal dynamics, total length and weight of the host have been found to influence the infection of Asian tapeworm in the hypereutrophic lake (Zargar et al. 2012a). However, none of the study has used integrative approach to elucidate the predictors responsible for the progression of infection and degradation of health status of fish under enhanced stressed conditions. Against this backdrop, we investigated the predictors of $A$. oreini infection in three fish species of genus Schizothorax across intra-lake eutrophic gradient and the effect of infection on the health traits of fish.

The main aims of this study were: (1) to analyse the effect of intra-lake pollution gradient on the infection pattern of the A. oreini; (2) to investigate how water quality affects the copepod density and consequently alters the infection pattern; and (3) to assess the indirect effect on the health status of fish as reflected by condition based indices. It was predicted that Adenoscolex oreini might show alteration in the infection level across intra eutrophic gradient and among fish species due to deterioration of water quality,
Table 1. Brief description of investigated lake of northwest Himalayan Region

\begin{tabular}{ll}
\hline \hline Characteristics & Anchar lake \\
\hline Latitude & $34^{\circ} 14^{\prime} \mathrm{N}$ \\
Longitude & $74^{\circ} 78^{\prime} \mathrm{E}$ \\
Elevation & $1584 \mathrm{~m} \mathrm{amsl}^{2 \mathrm{a}}$ \\
Total surface area & $6 \cdot 6 \mathrm{~km}^{2 \mathrm{a}}$ \\
Maximum depth & $3 \mathrm{~m}$ \\
Lake type & Amictic shallow lake \\
Pollution status & Hypertrophic \\
\hline \hline
\end{tabular}

a Khanday et al. (2016).

b Shah et al. (2013).

c Zargar et al. (2012c).

planktonic community and host features. In addition we supposed that the copepod density, seasonality of infection and water quality are intimately related with each other and influence the fish health status.

\section{MATERIALS AND METHODS}

\section{Study area}

The Kashmir Valley is positioned between the northwest and southeast of the Himalaya $\left(33^{\circ} 01^{\prime}-\right.$ $35^{\circ} 00^{\prime} \mathrm{N}$ lat.; $73^{\circ} 48^{\prime}-75^{\circ} 30^{\prime} \mathrm{E}$ long.) at an elevation of $\geqslant 1500 \mathrm{~m}$. The Anchar Lake $\left(34^{\circ} 01^{\prime} \mathrm{N}, 74^{\circ} 02^{\prime} \mathrm{E}\right)$, a hypereutrophic lentic water body located in the northwest side of Srinagar city, was selected for the present investigation (Table 1 and Fig. 1). The lake has been considered as monbasined with surface area of $6.6 \mathrm{~km}^{2}$.

The temperature in the month of January (coldest month) and July (warmest) ranges between -2 to $3{ }^{\circ} \mathrm{C}$ and $34-35^{\circ} \mathrm{C}$, respectively. The lake is fed by river Sind and also by number of springs present in its basin itself and along its periphery. The major portion of the lake is occupied by different types of submerged and free-floating macrophytes. The lake possesses about $1.69 \mathrm{~km}^{2}$ as open water and rest of the lake has now changed into marshland (Khanday et al. 2016). In addition to influx of household wastage from human habitations, the lake has been further reduced due to illegal encroachments by local population. The maximum length, breadth and depth are 3.55 , $0.65 \mathrm{~km}$ and $3.5 \mathrm{~m}$, respectively. Four sites were selected for the present study - Anchar Inlet (AI, $34^{\circ} 08^{\prime}-89^{\circ} 07^{\prime} \mathrm{N}$ and $74^{\circ} 47-69^{\circ} 2$; Elevation, 1596), Anchar Centre (AC, 34 $4^{\circ} 8-72^{\circ} 5$ and $74^{\circ} 47^{\prime}-43^{\circ} 7$; Elevation 1594), Anchar Ghat (AG, $34^{\circ} 8^{\prime}-75^{\circ}$ and

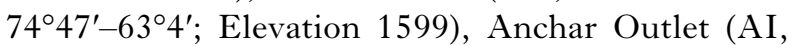
$34^{\circ} 08^{\prime}-43^{\circ} 8^{\prime}$ and $74^{\circ} 46^{\prime}-42^{\circ} 8^{\prime}$, Elevation, 1589).

\section{Water sampling}

The water quality of the Lake was carried out as per the international standards (CSIR, 1974; Mackereth 


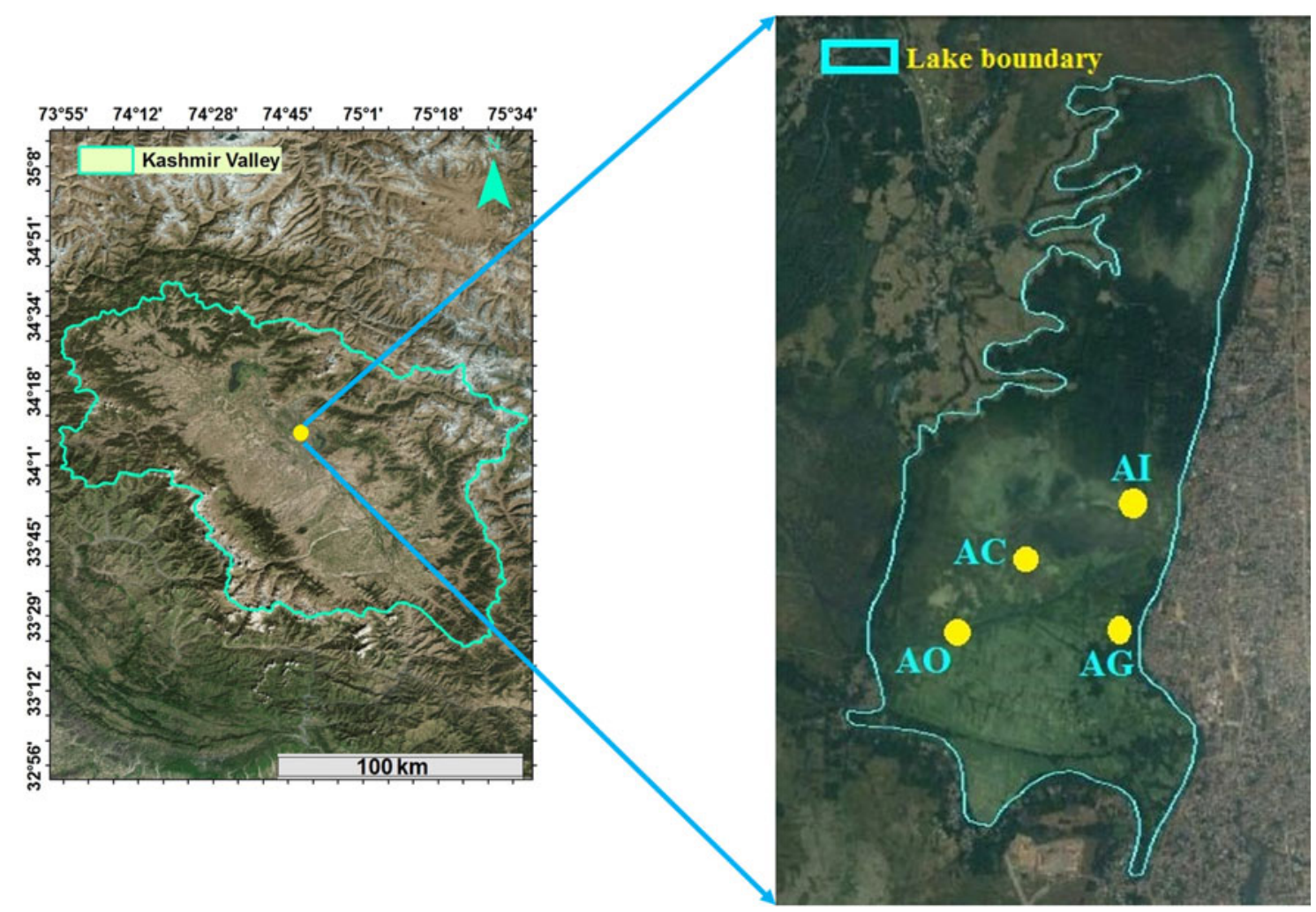

Fig. 1. Map of the study sites in the Anchar lake.

et al. 1978; APHA, 2005). The analysis of some of the parameters including water temperature, transparency and conductivity were conducted on the spot and rest of the physicochemical features were assessed in the laboratory. For estimation of dissolved oxygen (DO), water samples were fixed on the sampling spot and were then analysed in the lab as per azide modification of the Winkler method (APHA, 2005). The other measurements of water quality were assessed by using the methods/equipments as prescribed by CSIR (1974), Mackereth et al. (1978) and CSIR (1974). The water temperature, transparency, $\mathrm{pH}$ and conductivity were measured by using the Celsius mercury thermometer calibrated up to $0 \cdot 1{ }^{\circ} \mathrm{C}$, Secchi disc, digital $\mathrm{pH}$ meter (Microprocessor $\mathrm{pH}$ System-1011E) and Systronics model 104 conductivity meter, respectively. Total hardness of the samples was analysed by the EDTA method (CSIR, 1974), while as total alkalinity and chloride content of water samples was estimated by using Mackereth et al. (1978). Ammonia-nitrogen $\left(\mathrm{NH}_{3}-\mathrm{N}\right)$ and nitrate-nitrogen $\left(\mathrm{NO}_{3}-\mathrm{N}\right)$ was estimated by using the phenate method (APHA, 2005) and salicylate method (CSIR, 1974).

\section{Host, copepod and parasite collection}

In total, 417 specimens including 142 individuals of Schizothorax niger, 138 individuals of Schizothorax curvifrons and 137 individuals of Schizothorax esocinus were examined. Fish samples, caught by fishermen by using traditional gears (nets), were carried to laboratory for further investigation, where morphometric indices such as total length (TL), standard length (SL), and body weight (BW) and sex for each fish specimen was estimated. The length-weight (L-W) relationship, condition factor (Fulton's index) and gonadosomatic index (GSI) were determined according to the following equations:

Length-weight relationship: $W=a L^{\mathrm{b}}$, (Le Cren's, 1951)

Condition factor/Fulton's index: $K=\mathrm{W} / L^{3} \times 10^{5}$, (De Vlaming et al. 1982)

GSI $=$ Gonad weight $/$ body $\quad$ weight $\times 100 . \quad($ De Vlaming et al. 1982)

Copepods were obtained from four study sites from the Anchar Lake by plankton net of $64 \mu \mathrm{m}$ mesh size. The plankton copepods were quantified by sieveing $10 \mathrm{~L}$ of water through planktonic net with the help of Van Dorn water sampler at each sampling spot upto $100 \mathrm{~m}$. The collected content was transferred to collection vial where it was fixed in buffered $4 \%$ formalin solution. The sample was carried to laboratory where it was concentrated to a known volume and shaken gently. The quantitative estimation of copepod was done using SedgwickRafter cell with the dimensions of $50 \times 20 \times 1 \mathrm{~mm}^{3}$, following the method given in APHA (2005). Counting of planktonic copepods was carried out 
by taking $1 \mathrm{~mL}$ of collected sample in a SedgwickRafter cell and the entire content were counted. The collected species were identified with the help of standard taxonomic works (Edmondson et al. 1956) and Battish (1992). The copepod densities (as individuals per litre) were estimated as per Wanganeo and Wanganeo (2006) with some modification.

$$
\text { Number of Copepods ' } n^{\prime}=C \times 1000 \mathrm{~mm}^{2} / \mathrm{ADE}
$$

where, $C=$ the number of copepods recorded; $A=$ the area of field of microscope; $D=$ the depth of field (SRC depth) in $\mathrm{mm} ; E=$ the number of fields counted

$$
\begin{array}{r}
\text { Number of copepods } / 1=n \times \text { vol. of concentrate } \\
\qquad(m L) / \text { vol. (liters) of water filtered }
\end{array}
$$

The fish samples were examined for the presence of $A$. oreini by using the method of Ergens and Lom (1970). The collected caryophylledian tapeworms were immediately killed in as flash containing saline at $60-80^{\circ} \mathrm{C}$. The tapeworms were then shaken for 20-30 s. The fixation of the scolex was carried out separately by placing it on a clean glass slide and then placing a clean cover slip over it (Carnoy's fixative; cf. Weesner, 1968). The remaining body of cetode was fixed by keeping it between two slides for 5-10 min, while as comparatively thicker samples were kept in carnoy's fixative for longer duration. The specimens were finally transferred from carnoy's fixative to the $70 \%$ alcohol in order to remove excess of fixative. All the collected specimens were then fixed in the mixture of alcohol and glycerol (70\% alcohol with 5\% glycerol).

\section{Data analysis}

The infection descriptors [prevalence, mean intensity (MI) and mean abundance (MA)] were estimated by Bush et al. (1997) and Margolis et al. (1982). Inter-species and within-lake differences in prevalence were statistically tested by the Chisquare $\left(\chi^{2}\right)$ test. Differences in MI and MA across sampling sites and host species were tested by oneway ANOVA. Seasonal difference in prevalence was assessed by the $\chi^{2}$ test, whereas MI and MA were statistically tested by one-way ANOVA. Correlation analysis was carried out between different water quality parameters and prevalence (\%) and between tapeworm abundance and plankton abundance. The $\chi^{2}$ test was used to test the effect of body length, sex and condition factor on the prevalence of $A$. oreini. Generalized Linear Model (GLM) was used to show the effect of site, month and length on the intensity of $A$. oreini and copepod abundance. Multiple comparison test [Tukey HSD (honest significant differences)] was carried out wherever needed after it was clear that there is overall significant difference. The regression statistics and curves were used for the comparison of $\mathrm{L}-\mathrm{W}$ relationship among different sites and the slopes of $\log$-transformed data $[\log (X+1)$ was used to deal with zero and negative values] related to parasitic burden by Pearson's correlation. To test for an effect of MI on health indicators as reflected by GSI and condition factor, infected fish were tested for differences in slopes and intercepts.

\section{RESULTS}

\section{Physicochemical features of water}

The overall variation of various physicochemical features along with average ( \pm S.D.) is presented in Table 1. From the data it is evident that physicochemical features varied significantly $(P<0 \cdot 05)$ across study sites. The results showed that this lake has attained highly eutrophic condition. Previous researchers have found that heavy nutrient loading from the municipal drains, household and agricultural waste has drastically deteriorated the water quality of this lake and therefore it has been categorised as the Hypereutrophic lake (Pandit and Yousuf, 2002). The data from the present study also confirm their findings. In addition, the physicochemical features also showed intra-lake eutrophic gradient. The site close to human habitation showed significantly $(P<0 \cdot 05)$ low water quality as compared with site near inlet (AI), which depicted pristine conditions. As per the International standards, AI, Anchar Centre and Anchar Ghat were categorized as least eutrophic, eutrophic and hypertrophic sites, respectively. Anchar outlet showed same trophic condition as that of Anchar Centre (Table 1). Overall, the lake shows signs of accelerated rate of cultural eutrophication due to the enhanced stress and strain of anthropogenic interference.

\section{Variation of $A$. oreini infection among different hosts}

Significant variation in the $A$. oreini infection across different fish species was observed during the present study with highest prevalence recorded in S. niger $\left(\%=36 \cdot 74, \chi^{2}=14 \cdot 22, \quad P=0.0001\right)$ and least in $S$. esocinus $(\%=15 \cdot 7)$. The prevalence among three different fish species when compared statistically revealed significant differences between $S$. niger vs $S$. curvifrons $(P=0.007)$ and $S$. niger vs $S$. esocinus $(P=0 \cdot 0001)$, while insignificant variation was observed between $S$. curvifrons vs $S$. esocinus $(P=0 \cdot 44)$ ('Table 2).

\section{Intra-lake variation of $A$. oreini infection}

The overall prevalence of $A$. oreini in three species was significantly higher in Anchar Ghat 
Table 2. Intra-lake variation of physicochemical features of water in Anchar Lake

\begin{tabular}{lcccc}
\hline \hline Parameter & Anchar Inlet $(\mathrm{AI})$ & Anchar Centre $(\mathrm{AC})$ & AncharGhat $(\mathrm{AG})$ & Anchar Outlet $(\mathrm{AO})$ \\
\hline Water temp. $\left({ }^{\circ} \mathrm{C}\right)$ & $16 \cdot 9 \pm 5 \cdot 7^{\mathrm{B}}$ & $17 \cdot 5 \pm 7 \cdot 49^{\mathrm{A}}$ & $17 \cdot 9 \pm 3 \cdot 3^{\mathrm{C}}$ & $17 \cdot 3 \pm 7 \cdot 12^{\mathrm{A}}$ \\
Depth $(\mathrm{m})$ & $1 \cdot 3 \pm 0 \cdot 36^{\mathrm{A}}$ & $1 \cdot 59 \pm 0 \cdot 19^{\mathrm{B}}$ & $0 \cdot 75 \pm 0 \cdot 13^{\mathrm{C}}$ & $1 \cdot 5 \pm 0 \cdot 2^{\mathrm{D}}$ \\
Transparency $(\mathrm{m})$ & $0 \cdot 76 \pm 0 \cdot 24^{\mathrm{D}}$ & $0 \cdot 6 \pm 0 \cdot 1^{\mathrm{B}}$ & $0 \cdot 50 \pm 0 \cdot 0^{\mathrm{A}}$ & $0 \cdot 7 \pm 0 \cdot 2^{\mathrm{C}}$ \\
pH & $7 \cdot 52 \pm 0 \cdot 66^{\mathrm{C}}$ & $7 \cdot 06 \pm 0 \cdot 35^{\mathrm{A}}$ & $7 \cdot 02 \pm 0 \cdot 55^{\mathrm{A}}$ & $7 \cdot 35 \pm 0 \cdot 25^{\mathrm{B}}$ \\
Conductivity $(\mu \mathrm{S})$ & $236 \cdot 25 \pm 11 \cdot 08^{\mathrm{A}}$ & $213 \cdot 63 \pm 2 \cdot 06^{\mathrm{A}}$ & $254 \cdot 5 \pm 9 \cdot 53^{\mathrm{B}}$ & $220 \pm 3 \cdot 1^{\mathrm{C}}$ \\
Dissolved oxygen $\left(\mathrm{mg} \mathrm{L}^{-1}\right)$ & $4 \cdot 2 \pm 0 \cdot 14^{\mathrm{B}}$ & $2 \cdot 05 \pm 0 \cdot 83^{\mathrm{A}}$ & $2 \cdot 57 \pm 0 \cdot 63^{\mathrm{A}}$ & $3 \pm 0 \cdot 85^{\mathrm{A}}$ \\
Free CO $_{2}\left(\mathrm{mg} \mathrm{L}^{-1}\right)$ & $22 \cdot 52 \pm 1 \cdot 73^{\mathrm{AB}}$ & $20 \pm 1 \cdot 57^{\mathrm{B}}$ & $29 \cdot 82 \pm 4 \cdot 08^{\mathrm{BC}}$ & $21 \cdot 1 \pm 1 \cdot 45^{\mathrm{D}}$ \\
Alkalinity $\left(\mathrm{mg} \mathrm{L}^{-1}\right)$ & $218 \cdot 56 \pm 11 \cdot 36^{\mathrm{A}}$ & $233 \cdot 45 \pm 14 \cdot 6^{\mathrm{A}}$ & $267 \cdot 05 \pm 5 \cdot 56^{\mathrm{A}}$ & $231 \pm 9 \cdot 9^{\mathrm{A}}$ \\
Chloride $\left(\mathrm{mg} \mathrm{L}^{-1}\right)$ & $19 \cdot 2 \pm 1 \cdot 65^{\mathrm{A}}$ & $22 \cdot 55 \pm 3 \cdot 32^{\mathrm{B}}$ & $33 \cdot 42 \pm 9 \cdot 09^{\mathrm{C}}$ & $21 \cdot 1 \pm 4 \cdot 1^{\mathrm{D}}$ \\
Ammonia-N $\left(\mu \mathrm{g} \mathrm{L}^{-1}\right)$ & $424 \cdot 6 \pm 82 \cdot 16^{\mathrm{A}}$ & $492 \cdot 77 \pm 27 \cdot 8^{\mathrm{AC}}$ & $540 \cdot 0 \pm 27 \cdot 08^{\mathrm{D}}$ & $480 \pm 26 \cdot 1^{\mathrm{AB}}$ \\
Nitrate-N $\left(\mu \mathrm{g} \mathrm{L}^{-1}\right)$ & $221 \cdot 52 \pm 6 \cdot 11^{\mathrm{A}}$ & $240 \cdot 83 \pm 10 \cdot 10^{\mathrm{B}}$ & $244 \cdot 62 \pm 9 \cdot 03^{\mathrm{C}}$ & $238 \pm 9 \cdot 9^{\mathrm{C}}$ \\
Total phosphate $\left(\mu \mathrm{g} \mathrm{L}^{-1}\right)$ & $216 \cdot 83 \pm 49 \cdot 22^{\mathrm{A}}$ & $257 \cdot 12 \pm 5 \cdot 49^{\mathrm{B}}$ & $244 \cdot 0 \pm 19 \cdot 68^{\mathrm{C}}$ & $255 \cdot 01 \pm 5 \cdot 11^{\mathrm{C}}$ \\
Total Hardness $\left(\mathrm{mg} \mathrm{L}^{-1}\right)$ & $130 \cdot 43 \pm 49 \cdot 22^{\mathrm{A}}$ & $166 \cdot 12 \pm 55 \cdot 4^{\mathrm{B}}$ & $188 \cdot 72 \pm 51 \cdot 73^{\mathrm{C}}$ & $143 \pm 50 \cdot 1^{\mathrm{A}}$ \\
\hline
\end{tabular}

Similar superscript within the same row designates the insignificant differences

(AG: $\left.\%=44 \cdot 62, \chi^{2}=32 \cdot 69, P=0 \cdot 0001\right)$ compared with Anchar Centre $(\mathrm{AC}: \%=21 \cdot 44)$ and Anchar Inlet $(\mathrm{AI}: \%=8 \cdot 01)$. The hypereutrophic site, i.e. AG showed significantly $(P=0 \cdot 0001)$ greater MI $(16 \cdot 36 \pm 5 \cdot 51)$ and MA $(6 \cdot 59 \pm 3 \cdot 45$; Table 3$)$. The hypertrophic site further showed significant variation in MI and MA when compared with eutrophic and least eutrophic sites (AG vs AC, $P=0 \cdot 0001$; $\mathrm{AG}$ vs AI, $P=0.0001$; AC vs AI, $P=0.4$; $\mathrm{AO}$ vs AG, $P=0 \cdot 0001$ ), whereas eutrophic and least eutrophic sites showed insignificant variation (AG vs AC, $P=0.0001$; AG vs AI, $P=0.0001$; AC vs AI, $P=0.0001$; AC vs AI, $P=0.83$ and $\mathrm{AO}$ vs AG, $P=0 \cdot 0001)$.

\section{Seasonal variation of infection and copepod density}

The infection indices (Prevalence, MI and MA) showed clear monthly and seasonal pattern with the maximum infection level in summer months and least in winter months. All three fish species showed significant $(P<0 \cdot 05)$ seasonality in prevalence across different seasons. MI and MA also showed similar trend across different months and seasons, except in $S$. esocinus, which showed insignificant difference between different seasons (Table 4). All the infection indices (Prevalence, MI and MA) peaked from May to August and showed decline from that onwards.

Table 3. Variation of infection with reference to host species and study site. Comparative statistical analysis $\left(\chi^{2}\right.$ and one-way ANOVA) is also given

\begin{tabular}{|c|c|c|c|c|c|}
\hline Parameter & Sample size & Host infected & Prevalence (range) & MI & MA \\
\hline \multicolumn{6}{|c|}{ Variation across different host species } \\
\hline Schizothorax niger $(S n)$ & 142 & 47 & $36 \cdot 74(7 \cdot 14-88 \cdot 88)$ & $5 \cdot 78 \pm 5 \cdot 08$ & $2 \cdot 89 \pm 4 \cdot 25$ \\
\hline S. curvifrons $(S c)$ & 138 & 26 & $18 \cdot 43(8 \cdot 33-36 \cdot 36)$ & $10 \cdot 04 \pm 7 \cdot 56$ & $2 \cdot 30 \pm 3 \cdot 37$ \\
\hline S. esocinus $(\mathrm{Se})$ & 137 & 21 & $15 \cdot 70(0-46 \cdot 15)$ & $8 \cdot 81 \pm 8 \cdot 54$ & $2 \cdot 17 \pm 3 \cdot 02$ \\
\hline$\chi^{2}$ test for Prevalence & $\chi^{2}$ & Df & $P$ value & & \\
\hline Overall & $14 \cdot 22$ & 2 & $0 \cdot 001 *$ & & \\
\hline$S n$ vs $S c$ & $7 \cdot 38$ & 1 & $0 \cdot 007 *$ & & \\
\hline Sn vs Se & $11 \cdot 9$ & 1 & $0 \cdot 001 *$ & & \\
\hline$S c$ vs $S e$ & $0 \cdot 6$ & 1 & $0 \cdot 44 \mathrm{~ns}$ & & \\
\hline \multicolumn{6}{|l|}{ Inter-lake variation } \\
\hline AncharGhat (AG) & 104 & 43 & $44 \cdot 62(16 \cdot 6-88 \cdot 8)$ & $16 \cdot 36 \pm 5 \cdot 51$ & $6 \cdot 59 \pm 3 \cdot 45$ \\
\hline Anchar Centre (AC) & 102 & 22 & $21 \cdot 44(9 \cdot 09-63 \cdot 6)$ & $4 \cdot 01 \pm 3 \cdot 18$ & $0 \cdot 72 \pm 0 \cdot 54$ \\
\hline Anchar Inlet (AI) & 103 & 8 & $8 \cdot 01(0-16 \cdot 6)$ & $1 \cdot 66 \pm 1 \cdot 5$ & $0 \cdot 17 \pm 0 \cdot 15$ \\
\hline Anchar Outlet (AO) & 96 & 20 & $17 \cdot 7(53 \cdot 8-6 \cdot 6)$ & $3 \cdot 33 \pm 2 \cdot 43$ & $0 \cdot 48 \pm 0 \cdot 36$ \\
\hline$\chi^{2}$ test & $\chi^{2}$ & Df & $P$ value & & \\
\hline Prevalence & $32 \cdot 69$ & 3 & $0 \cdot 0001$ & & \\
\hline \multicolumn{6}{|l|}{ One-way ANOVA } \\
\hline \multirow[t]{2}{*}{ MI } & & & MA & & \\
\hline & $F$ value & $P$ value & & $F$ value & $P$ value \\
\hline Overall & $F_{3,35}=32 \cdot 66$ & $0 \cdot 0001$ & Overall & $F_{3,35}=27 \cdot 50$ & $0 \cdot 0001$ \\
\hline
\end{tabular}


Table 4. Seasonal alteration of $A$. oreini in three fish species and copepod density in Anchar lake

\begin{tabular}{|c|c|c|c|c|c|c|}
\hline Season & Winter & Spring & Summer & Autumn & $\chi^{2}$ & $P$ value \\
\hline \multicolumn{7}{|l|}{ Prevalence } \\
\hline $\mathrm{Sn}$ & $11 \cdot 26$ & $25 \cdot 87$ & $75 \cdot 55$ & $34 \cdot 26$ & $48 \cdot 3$ & $0 \cdot 0001$ \\
\hline $\mathrm{Sc}$ & $9 \cdot 44$ & $19 \cdot 31$ & $29 \cdot 04$ & $15 \cdot 92$ & $60 \cdot 46$ & $0 \cdot 0001$ \\
\hline $\mathrm{Se}$ & $3 \cdot 33$ & $16 \cdot 05$ & $29 \cdot 27$ & $14 \cdot 14$ & $77 \cdot 76$ & $0 \cdot 0001$ \\
\hline MI & & & & & ANOVA & \\
\hline $\mathrm{Sn}$ & $2 \cdot 33 \pm 0 \cdot 57$ & $7 \cdot 88 \pm 4 \cdot 59$ & $11 \cdot 07 \pm 5 \cdot 49$ & $1 \cdot 85 \pm 1 \cdot 03$ & $F_{3,11}=4 \cdot 52$ & $0 \cdot 04$ \\
\hline $\mathrm{Sc}$ & $2 \cdot 66 \pm 1 \cdot 52$ & $10 \cdot 94 \pm 3 \cdot 95$ & $20 \cdot 25 \pm 4 \cdot 13$ & $6 \cdot 33 \pm 4 \cdot 51$ & $F_{3,11}=12 \cdot 5$ & $0 \cdot 002$ \\
\hline $\mathrm{Se}$ & $1 \cdot 33 \pm 2 \cdot 3$ & $13 \cdot 66 \pm 9 \cdot 01$ & $17 \cdot 77 \pm 2 \cdot 54$ & $3 \cdot 83 \pm 2 \cdot 02$ & $F_{3,11}=8.98$ & $0 \cdot 006$ \\
\hline \multicolumn{7}{|l|}{ MA } \\
\hline $\mathrm{Sn}$ & $0 \cdot 25 \pm 0 \cdot 07$ & $2 \cdot 01 \pm 1 \cdot 54$ & $8 \cdot 77 \pm 5 \cdot 03$ & $0 \cdot 55 \pm 0 \cdot 39$ & $F_{3,11}=6 \cdot 86$ & $0 \cdot 01$ \\
\hline $\mathrm{Sc}$ & $0 \cdot 26 \pm 0 \cdot 16$ & $2 \cdot 05 \pm 0 \cdot 48$ & $5 \cdot 81 \pm 1 \cdot 77$ & $1 \cdot 08 \pm 0 \cdot 81$ & $F_{3,11}=17 \cdot 8$ & $0 \cdot 001$ \\
\hline $\mathrm{Se}$ & $0 \cdot 13 \pm 0 \cdot 23$ & $2.99 \pm 4.05$ & $5 \cdot 18 \pm 2 \cdot 84$ & $0 \cdot 54 \pm 0 \cdot 31$ & $F_{3,11}=2 \cdot 77$ & $0 \cdot 11$ \\
\hline Copepod density & $1216 \cdot 66 \pm 202 \cdot 1$ & $1575 \pm 283 \cdot 9$ & $1583 \cdot 33 \pm 236 \cdot 3$ & $1362 \cdot 5 \pm 316 \cdot 96$ & $F=11 \cdot 08$ & $0 \cdot 003$ \\
\hline
\end{tabular}

Correlation between water quality, prevalence of cestode and copepod density

The percentage (prevalence) of infection showed significant positive correlation (for prevalence in Schizothrorax niger, $\mathrm{rs}=0.85, P<0.01$; For $S$. curvifrons, $\mathrm{rs}=0.78, P<0.01$; for $S$. esocinus, $\mathrm{rs}=$ $0.69, P<0.05)$ with the water temperature in all three fish species (Fig. 2). Only two species of copepods were observed during the present study. The density of Cyclops scutifer depicted significant correlation with water temperature ( $\mathrm{rs}=0.78, P<$ $0.01)$ and with prevalence of infection ( $\mathrm{rs}=0.69$, $P<0.05 \&$ rs $=0.64, P<0.05)$, whilst Eucyclops agilis showed insignificant correlation with water temperature (rs $=0.49, P>0.05)$ and with prevalence of infection ( $\mathrm{rs}=0 \cdot 55, P>0 \cdot 05)$.

\section{Influence of host length and sex on A. oreini}

Different length groups showed insignificant variation $(P>0 \cdot 05)$ in cestode infection. The prevalence insignificantly increased $(P>0.05)$ from lower length group $(\%=15)$ to higher length group in S. curvifrons $\left(\%=35, \chi^{2}=1 \cdot 57, P=0 \cdot 66\right)$, whereas it showed first increased prevalence in $S$. niger and then prevalence decreased $\left(\chi^{2}=3 \cdot 33, P=0 \cdot 34\right)$. The case with $S$. esocinus, however, was different because it showed same trend in prevalence in first three length groups and then it increased $\left(\chi^{2}=\right.$ $3 \cdot 75, P=0 \cdot 29)$.

A
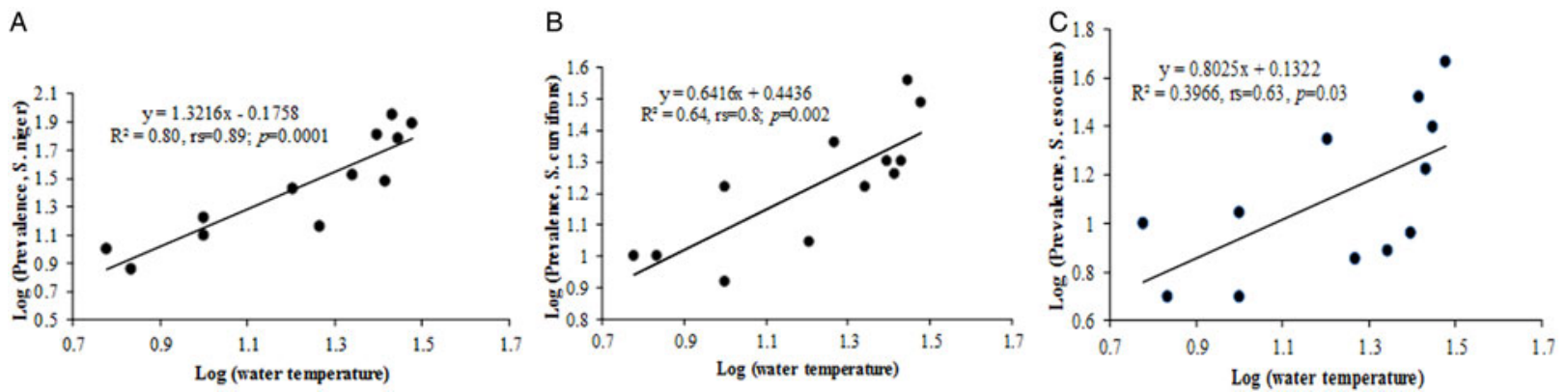

Fig. 2. Scatter plot between water temperature and prevalence: (A) Schizothorax niger, (B) S. curvifrons, (C) S. esocinus.
Sex of host significantly $\left(\chi^{2}=8 \cdot 77, P=0 \cdot 003\right)$ influenced prevalence in $S$. niger as infection level was high in females (Prevalence $=50 \%$ ) than in males (Prevalence $=25 \cdot 71 \%)$. Similar trend was observed in $S$. curvifrons with greater infection observed in females $\left(26.66 \%, \chi^{2}=3.48, P=0.062\right.$, tendency towards significance). The prevalence, however, showed insignificant variation in infection $\left(\chi^{2}=0 \cdot 001, P=0.97\right)$.

\section{Generalized Linear Model analysis}

GLM analysis clearly shows that the site $(F=$ 423.69, $P=0.001$ for $\mathrm{MI} ; F=4.44, P=0.008$ for copepod abundance) and the month $(F=2 \cdot 95, P=$ 0.045 for MI; $F=35 \cdot 2, P=0.0001)$ are the important factors, which influence the cestode infection (Table 5).

\section{Effect of $A$. oreini on the health status of fish}

GSI was significantly low $(P<0.05)$ in the parasitized fish at all sampling sites and also showed variation across the site with significantly high GSI at AI (Table 6). The qualitative health indicator, i.e. condition factor $(k)$ was significantly higher in uninfected fishes compared with infected fishes in $S$. niger and $S$. curvifrons $(t$-test $=5 \cdot 6, P<0 \cdot 0001$ for $S$. niger and $t$-test $=3 \cdot 82, P<0 \cdot 003)$, whereas condition factor $(k)$ was insignificantly high in uninfected fishes compared with infected fishes in 
Table 5. Generalized Linear Model showing the effect of site, month and length on the intensity of A. oreini and abundance of copepod

\begin{tabular}{|c|c|c|c|c|c|}
\hline & SS & Df & M S & $\mathrm{F}$ & $P$ value \\
\hline \multicolumn{6}{|l|}{ Mean Intensity } \\
\hline Corrected model & $1077 \cdot 30$ & 9 & $119 \cdot 7$ & $151 \cdot 765$ & $0 \cdot 0001$ \\
\hline Intercept & $235 \cdot 79$ & 1 & $235 \cdot 79$ & $298 \cdot 96$ & $0 \cdot 0001$ \\
\hline Site & $1002 \cdot 52$ & 3 & $334 \cdot 17$ & $423 \cdot 692$ & $0 \cdot 0001$ \\
\hline Month & 6.978 & 3 & $2 \cdot 326$ & 2.949 & $0 \cdot 045$ \\
\hline Length & $0 \cdot 213$ & 3 & $0 \cdot 071$ & $0 \cdot 09$ & $0.965 \mathrm{~ns}$ \\
\hline Error & $29 \cdot 971$ & 38 & $0 \cdot 789$ & & \\
\hline \multicolumn{6}{|l|}{ Copepod abundance } \\
\hline Corrected model & $3 \cdot 632$ & 6 & $605385 \cdot 243$ & $19 \cdot 881$ & $0 \cdot 0001$ \\
\hline Intercept & $8 \cdot 37$ & 1 & $8 \cdot 37$ & $2 \cdot 75 E+03$ & $0 \cdot 0001$ \\
\hline Site & $415843 \cdot 22$ & 3 & $138614 \cdot 41$ & $4 \cdot 552$ & $0 \cdot 008$ \\
\hline Season & $3216468 \cdot 22$ & 3 & $1072156 \cdot 07$ & $35 \cdot 209$ & $0 \cdot 0001$ \\
\hline Error & $1248488 \cdot 02$ & 41 & $30450 \cdot 92$ & & \\
\hline
\end{tabular}

Table 6. Variation of Gonadasomic index and condition factor in uninfected and infected fish in two native fish across four study sites

\begin{tabular}{|c|c|c|c|c|}
\hline Site & AI & $\mathrm{AC}$ & $\mathrm{AG}$ & $\mathrm{AO}$ \\
\hline \multicolumn{5}{|l|}{ S. niger (GSI) } \\
\hline Uninfected & $11 \cdot 25 \pm 6 \cdot 65^{\mathrm{B}}$ & $6 \cdot 63 \pm 3 \cdot 49^{\mathrm{A}}$ & $4 \cdot 75 \pm 2 \cdot 97^{\mathrm{A}}$ & $3 \cdot 55 \pm 2 \cdot 49^{\mathrm{A}}$ \\
\hline Infected & $4 \cdot 83 \pm 4 \cdot 62^{\mathrm{A}}$ & $4 \cdot 51 \pm 4 \cdot 19^{\mathrm{A}}$ & $3 \cdot 24 \pm 3 \cdot 01^{\mathrm{A}}$ & $1 \cdot 95 \pm 2 \cdot 30^{\mathrm{A}}$ \\
\hline Overall & $8 \cdot 04 \pm 4 \cdot 54^{\mathrm{C}}$ & $5 \cdot 57 \pm 1 \cdot 50^{\mathrm{AB}}$ & $3 \cdot 99 \pm 1 \cdot 07^{\mathrm{A}}$ & $2 \cdot 75 \pm 1 \cdot 13^{\mathrm{A}}$ \\
\hline \multicolumn{5}{|c|}{ S. esocinus (GSI) } \\
\hline Uninfected & $6 \cdot 24 \pm 3 \cdot 45^{\mathrm{A}}$ & $5 \cdot 85 \pm 3 \cdot 25^{\mathrm{A}}$ & $5 \cdot 27 \pm 3 \cdot 26^{\mathrm{A}}$ & $5 \cdot 06 \pm 3 \cdot 25^{\mathrm{A}}$ \\
\hline Infected & $2 \cdot 58 \pm 3 \cdot 23^{\mathrm{A}}$ & $2 \cdot 25 \pm 2 \cdot 95^{\mathrm{A}}$ & $2 \cdot 08 \pm 2 \cdot 96^{\mathrm{A}}$ & $2 \cdot 29 \pm 3 \cdot 52^{\mathrm{A}}$ \\
\hline Overall & $4 \cdot 41 \pm 2 \cdot 59^{\mathrm{A}}$ & $4 \cdot 05 \pm 2 \cdot 54^{\mathrm{A}}$ & $3 \cdot 68 \pm 2 \cdot 25^{\mathrm{A}}$ & $3 \cdot 83 \pm 1 \cdot 74^{\mathrm{A}}$ \\
\hline \multicolumn{5}{|l|}{$S$. niger $(K)$} \\
\hline Uninfected & $1 \cdot 22 \pm 0 \cdot 22^{\mathrm{B}}$ & $0 \cdot 81 \pm 0 \cdot 12^{\mathrm{A}}$ & $0 \cdot 63 \pm 0 \cdot 19^{\mathrm{A}}$ & $0 \cdot 85 \pm 0 \cdot 05^{\mathrm{A}}$ \\
\hline Infected & $1 \cdot 15 \pm 0 \cdot 21^{\mathrm{C}}$ & $0 \cdot 59 \pm 0 \cdot 40^{\mathrm{A}}$ & $0 \cdot 58 \pm 0 \cdot 22^{\mathrm{AB}}$ & $0 \cdot 78 \pm 0 \cdot 06^{\mathrm{A}}$ \\
\hline Overall & $1 \cdot 22 \pm 0 \cdot 05^{\mathrm{B}}$ & $0 \cdot 81 \pm 0 \cdot 15^{\mathrm{A}}$ & $0 \cdot 63 \pm 0.03^{\mathrm{A}}$ & $0 \cdot 85 \pm 0 \cdot 05^{\mathrm{A}}$ \\
\hline \multicolumn{5}{|l|}{ S. esocinus $(K)$} \\
\hline Uninfected & $1 \cdot 10 \pm 0 \cdot 24^{\mathrm{A}}$ & $0 \cdot 86 \pm 0 \cdot 11^{\mathrm{A}}$ & $0.93 \pm 0.32^{\mathrm{A}}$ & $0 \cdot 89 \pm 0 \cdot 11^{\mathrm{A}}$ \\
\hline Infected & $1 \cdot 03 \pm 0 \cdot 10^{\mathrm{A}}$ & $1 \cdot 01 \pm 0 \cdot 22^{\mathrm{A}}$ & $0.95 \pm 0.32^{\mathrm{A}}$ & $0 \cdot 88 \pm 0 \cdot 13^{\mathrm{A}}$ \\
\hline Overall & $1 \cdot 065 \pm 0.05^{\mathrm{A}}$ & $0 \cdot 93 \pm 0 \cdot 11^{\mathrm{A}}$ & $0 \cdot 94 \pm 0 \cdot 02^{\mathrm{A}}$ & $0 \cdot 88 \pm 0 \cdot 007^{\mathrm{A}}$ \\
\hline
\end{tabular}

Different superscript in the same row shows significant differences

$S$. esocinus ( $t$ test $=0 \cdot 74, P=0 \cdot 47$ ). Linear regressions showed that fish health as reflected by GSI was significantly $(P<0 \cdot 05)$ predicted by infection intensity (Table 6 and Fig. 2). The coefficient (slope) from the $\mathrm{L}-\mathrm{W}$ regressions of infected fishes when compared among different study sites showed significant variation $\left(F_{3,8}=4 \cdot 9, P=0 \cdot 03\right.$, Table 7, Fig. 3). In addition, the slope from the $\mathrm{L}-\mathrm{W}$ regression was negatively related with parasite burden $(P<0 \cdot 05$, Table 8 ; Fig. 4$)$.

\section{DISCUSSION}

\section{Variation of $A$. oreini infection among three native fish} species

The study revealed significant variation of the infection level of $A$. oreini across different species of genus Schizothorax possibly due to varied type of feeding behaviour/food preferences in hosts. The role of feeding behaviour on the occurrence of parasitism in fish is well documented in the literature. The role of foraging behaviour, for example, has been reported as an important determinant of parasite communities (Knudsen et al. 2004; Valtonen et al. 2010). The feeding behaviour of different species of genus Schizothorax, which have been studies in past, revealed that these fishes are herbivores, and their diet is mainly composed of phytoplankton and rest contained aquatic invertebrates (Jan and Das, 1970). The variation in the uptake of intermediate hosts by the individuals of different species may also account for species-specific variation in the cestode infection. In addition, the influence of anthropogenic eutrophication on the food availability could also affect the dynamics of the infection in different fish species (Budria and Candolin, 2015). 
Table 7. Regression statistics of length-weight relationship (uninfected and infected fish) across different study sites

\begin{tabular}{|c|c|c|c|c|c|c|c|}
\hline & $R$ & RSQ & $\operatorname{Adj} R$ & Slope \pm s.E. & $95 \%$ interval & $t$ value & $P$ value \\
\hline \multicolumn{8}{|c|}{ Uninfected } \\
\hline AI & $0 \cdot 95$ & $0 \cdot 91$ & $0 \cdot 9$ & $2 \cdot 51 \pm 0 \cdot 14$ & $2 \cdot 2-2 \cdot 79$ & $17 \cdot 9$ & $0 \cdot 0001$ \\
\hline $\mathrm{AC}$ & $0 \cdot 96$ & $0 \cdot 93$ & $0 \cdot 93$ & $2 \cdot 57 \pm 0 \cdot 127$ & $2 \cdot 3-2 \cdot 8$ & $20 \cdot 2$ & $0 \cdot 0001$ \\
\hline $\mathrm{AG}$ & $0 \cdot 93$ & $0 \cdot 85$ & $0 \cdot 85$ & $2 \cdot 54 \pm 0 \cdot 18$ & $2 \cdot 2-2 \cdot 9$ & $14 \cdot 1$ & $0 \cdot 0001$ \\
\hline $\mathrm{AO}$ & $0 \cdot 89$ & $0 \cdot 8$ & $0 \cdot 79$ & $2 \cdot 33 \pm 0 \cdot 2$ & $1 \cdot 9-2 \cdot 7$ & $11 \cdot 5$ & $0 \cdot 0001$ \\
\hline \multicolumn{8}{|c|}{ Infected } \\
\hline AI & $0 \cdot 94$ & $0 \cdot 88$ & $0 \cdot 87$ & $2 \cdot 78 \pm 0 \cdot 179$ & $2 \cdot 42-3 \cdot 14$ & 14 & $0 \cdot 0001$ \\
\hline $\mathrm{AC}$ & $0 \cdot 93$ & $0 \cdot 86$ & $0 \cdot 86$ & $2 \cdot 48 \pm 0 \cdot 17$ & $2 \cdot 14-2 \cdot 82$ & $14 \cdot 7$ & $0 \cdot 0001$ \\
\hline $\mathrm{AG}$ & $0 \cdot 93$ & $0 \cdot 86$ & $0 \cdot 85$ & $2 \cdot 18 \pm 0 \cdot 15$ & $1 \cdot 87-2 \cdot 49$ & $14 \cdot 2$ & $0 \cdot 0001$ \\
\hline $\mathrm{AO}$ & 0.95 & $0 \cdot 89$ & $0 \cdot 89$ & $2 \cdot 76 \pm 0 \cdot 22$ & $2 \cdot 3-3 \cdot 22$ & $12 \cdot 6$ & $0 \cdot 0001$ \\
\hline
\end{tabular}
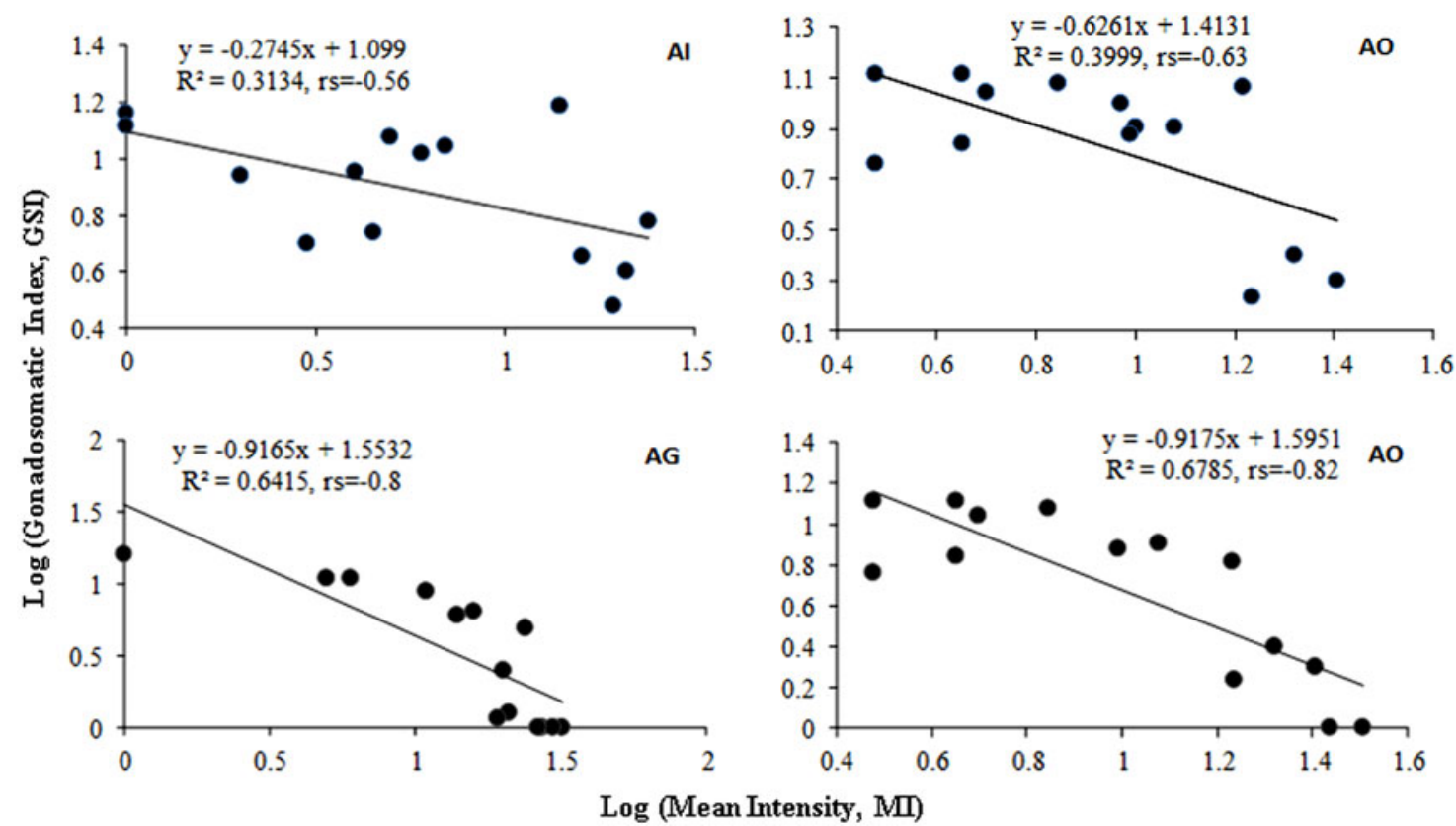

Fig. 3. Regression models showing the correlation between $\log$ (mean intensity) and log (GSI) in S. niger at Anchar Inlet (AI), Anchar Centre (AC), Anchar Ghat (AG) and Anchar Outlet (AO).

The habitat preference and restriction of lacustrine fish, $S$. niger in lentic water bodies favour more cestode infection, whereas better physiological and immunological condition of the S. esocinus may

Table 8. Correlation between parasite burden and slope of regression (length-weight relationship)

\begin{tabular}{lcccc}
\hline \hline & MI (AI) & MI (AC) & MI (AG) & MI (AO) \\
\hline MI (AI) & 1 & $0 \cdot 740^{* *}$ & $0 \cdot 903^{* *}$ & $1 \cdot 000^{* *}$ \\
MI (AC) & $0 \cdot 740^{* *}$ & 1 & $0 \cdot 713^{* *}$ & $0 \cdot 740^{* *}$ \\
MI (AG) & $0 \cdot 903^{* *}$ & $0 \cdot 713^{* *}$ & 1 & $0 \cdot 903^{* *}$ \\
MI (AO) & $1 \cdot 000^{* *}$ & $0 \cdot 740^{* *}$ & $0 \cdot 903^{* *}$ & 1 \\
Slope (AI) & $-0 \cdot 789^{* *}$ & $-0 \cdot 842^{* *}$ & $-0 \cdot 882^{* *}$ & $-0 \cdot 789^{* *}$ \\
Slope (AC) & $-0 \cdot 32$ & $-0 \cdot 711^{* *}$ & $-0 \cdot 27$ & $-0 \cdot 32$ \\
Slope (AG) & $-0 \cdot 670^{*}$ & $-0 \cdot 712^{* *}$ & $-0 \cdot 791^{* *}$ & $-0 \cdot 670^{*}$ \\
Slope (AO) & $-0 \cdot 646^{*}$ & $-0 \cdot 705^{*}$ & $-0 \cdot 789^{* *}$ & $-0 \cdot 646^{*}$ \\
\hline \hline
\end{tabular}

**Correlation is significant at the 0.01 level (2-tailed). * Correlation is significant at the 0.05 level (2-tailed). result in low prevalence of tapeworm. The past studies have revealed that parasitic resistance due to specific and non-specific immune responses also influences the infection pattern (Karvonen et al. 2003). However, it is early to say whether there exists any relationship between infection pattern of three native species and immune response. Moreover, an immunological study with regard to A. oreini of fish has not been carried out on large scale and the lack of information on this aspect calls for further investigation.

The effect of environmental change in the Anchar Lake may be also responsible for the above variation due to direct impact of deteriorated environment on host and parasite through altered physiological requirements (Brunner and Eizaguirre, 2016). The alteration in host behaviour (such as mate preference) (Budria and Candolin, 2015) and impairment in the host defences due to insufficient feeding 

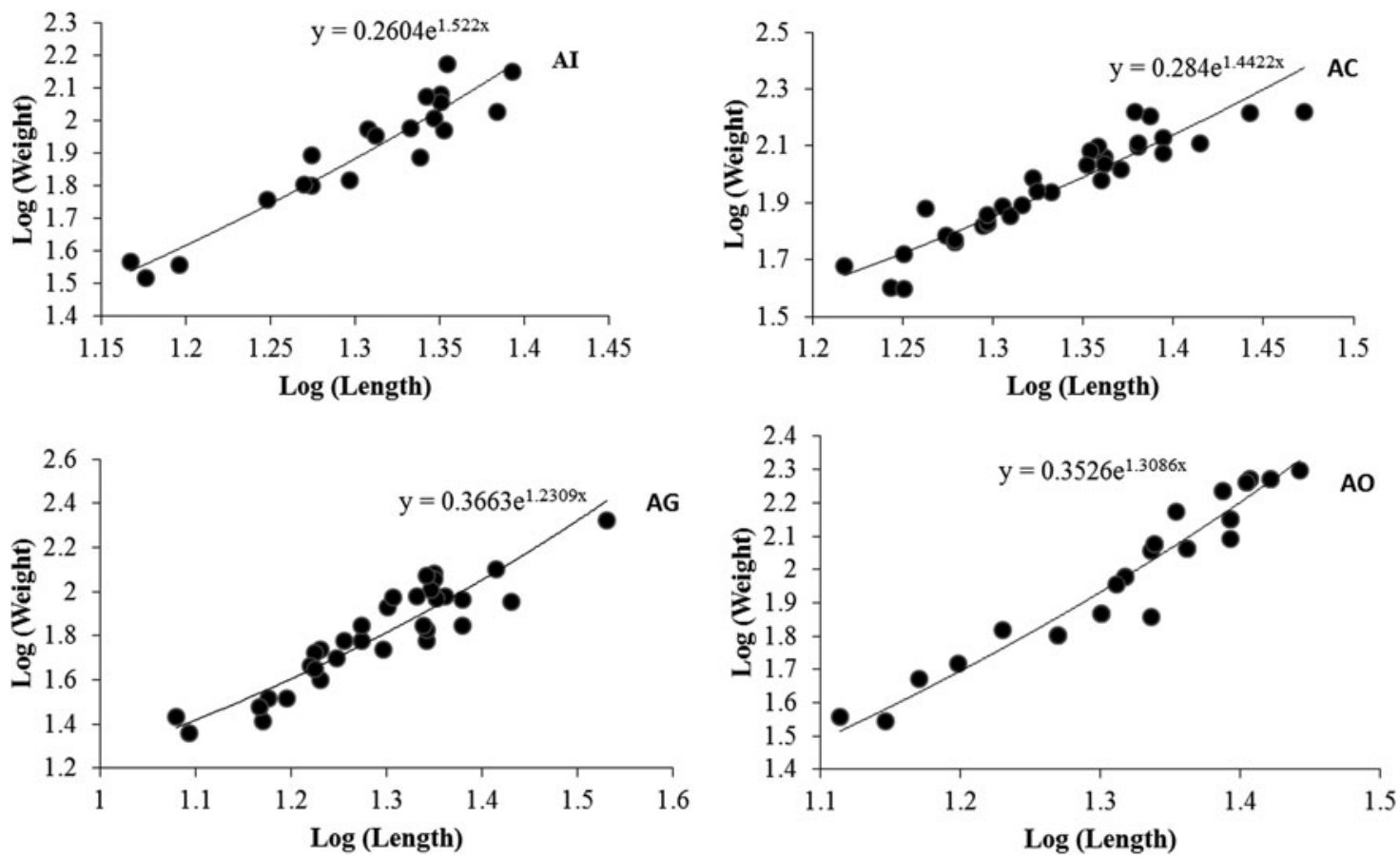

Fig. 4. Regression models showing the correlation between Log (Mean Intensity) and log (weight) in infected fish (pooled) at Anchar Inlet (AI), Anchar Centre (AC), Anchar Ghat (AG) and Anchar Outlet (AO).

behaviour have been also reported to be influenced by eutrophication (Brunner et al. 2014).

\section{Intra-lake variation of $A$. oreini infection}

The higher prevalence at the hypereutrophic site (Anchar Ghat) is due to the effect of highly stressful condition that weakens the immune system of host present there, and thus fish becomes safe haven for the Caryophyllied tapeworm to colonize. The enhanced eutrophic condition at this site may favour intermediate hosts as it has been stated that some invertebrates are favoured or show increased abundance under eutrophic conditions and consequently change the parasite history (McKenzie and Townsend, 2007). The high intensity of infection at highly eutrophic site in the present study could be due to inflow of municipal as well as other effluents released from the SKIMS, the only tertiary-care hospital in Kashmir (Bhat et al. 2001). Though municipal effluents have shown increase in prevalence in the myxozoan parasites of Notropis hudsonis (Marcogliese et al. 2009) there is scanty study on cestodes in general and Caryophyllaeid tapeworms in particular which show any relationship between municipal effluent and infection parameters. The results further revealed insignificant variation in the cestode infection between eutrophic and least eutrophic sites, which depicts that host in these locations are immunologically resistant to cestode infection. In previous studies, within-lake dynamics in fish parasites have shown considerable variation in the infection levels across different study sites. Karvonen et al. (2005) explained that the similarity of the parasite fauna is affected by reproductive behaviour, especially spawning period of host population and further demonstrated that geographical distance affected helminths across locations negatively.

\section{Monthly and seasonal variations of infection}

The results clearly showed seasonality in the infection level and further depicted that warmer months are suitable for the progression of $A$. oreini, which is likely due to the reduced generation time, resulting in the increased abundance of tapeworms in a shorter period. Previous studies have shown the importance of water temperature on different life stages of parasites vis-a-vis growth and progression (Brouder and Hoffnagle, 1997).

It is also clear from the empirical data that summer months are the most suitable for the occurrence of $A$. oreini, which is due to feasible environmental conditions for this particular parasite. As per climatic records of Kashmir valley, the July month (mean maximum temperature $32{ }^{\circ} \mathrm{C}$ ) is the hottest of the all months and it can be safely argued that $A$. oreini is adapted in higher range of temperature. The maturation of the $A$. oreini is seasonal and recruitment of the parasite has been reported in autumn (Dhar and Peerzada, 1989). The seasonality of $A$. oreini as reflected by the present study deviate from the past studies as it has been reported that some Caryophyllaeid tapeworms have two peaks of infection (one in spring and 
another in autumn, Milbrink, 1975). The lack of seasonality has been also attributed to the survival ability of Caryophyllaeus laticeps larvae in all months (Kulakovskaya, 1964). Furthermore, it has been earlier reported by Kennedy (1969) that highest infection for $C$. Laticeps was observed during April and May and declined in July. Inconsistencies prevailing in different studies with regard to monthly and seasonal variation of caryophylledians could be due to variation in the availability of infective stage (Kennedy, 1969). In addition, fish hormone levels are also predicted to influence the maturation of the infective stage of caryophylledians (Williams and Jones, 1994).

The MI and abundance was significantly higher during summer and lower in winter in all the three fish species showing that seasonality pattern is almost similar. The upsurge of intermediate hosts during the summer months may be primary cause for the highest prevalence of $A$. oreini infection in our study, which is well supported by the findings of Bertasso and Avenant-Oldewage (2005).

\section{Correlation between water quality, prevalence of cestode and copepod density}

The A. oreini showed significant variation in infection level in all the three fish species with respect to water quality. It is further evident from the results that infection level of $A$. oreini increased with the increase of temperature, which coincides with the increased abundance of the intermediate host at the peak of eutrophic conditions (Beer and German, 1993). Similar types of observations were observed by Zargar et al. (2012a), while working on the effect of water quality on the Asian tape worm in the Anchar Lake. As is evident from the data and from earlier reports (Zargar et al. 2012a) that eutrophication level in Anchar Lake reaches to peak level during summer months; such conditions are feasible for the growth and progression of the intermediate hosts and finally results in the larval transmission (Sandland and Goater, 2000). The temporal and spatial pattern of parasites including helminths has been found to be affected by various anthropogenic stresses (Zargar et al. 2012b; Shah et al. 2013; Budria and Candolin, 2014, 2015). Recent study has shown that complex interactions between water temperature and biotic factors determine the occurrence of parasite fauna, including trematodes and cestodes (Karvonen et al. 2013).

The result depicts that copepod density, especially $C$. scutifer significantly correlated with the infection of $A$. oreini and water quality. Planktonic copepods have showed their association with the cestode infection in past. Marcogliese and Esch $(1989 a, b)$, for example, revealed that planktonic cyclopoid species proved susceptible to the Asian tapeworm, while as benthic copepods were not susceptible to the infection. The low species diversity of copepods in the present study is in conformity with the recent study that indicate that copepod fauna decrease in lentic water bodies of Kashmir due to increase in the nutrient enrichment (Ping et al. 1996; Bhat, 2012). A study carried out by Bhat (2012) have revealed decrease in copepod species richness from seven recorded in 1980 s to four in Dal Lake, which is currently under eutrophic condition. The current study is, however, inconsistent with the findings of Malley et al. (1988) who revealed that cyclopoids are able to withstand stressful conditions. The availability of planktonic communities show association with trophic state of water bodies and are important for the progression of the life cycle of cestodes. While oligotrophic condition of lakes is favourable for the occurrence of copepods, eutrophic state reduces the population of copepods (Molzen, 2005). There is paucity of information with regard to the ecology and association of the natural intermediate host of $A$. oreini with the water quality, and therefore further studies are suggested in future.

\section{Influence of host length and sex on A. oreini}

The total length was insignificantly related with the infection of $A$. oreini. Various studies have shown length to be an important factor, which influence helminth occurrence in general and tapeworms in particular. It has been also demonstrated that various factors, especially ageing and surface area of fish have an impact on the helminth accumulation in fish (Koskivaara, 1992; Brouder, 1999; TekinOzan et al. 2008).

Results showed more infection burden (MI) of $A$. oreini in female hosts of $S$. niger and $S$. curvifrons compared with their male counter parts, which could be due to the host hormone level, feeding behaviour and favourable environment for colonization. The study on the Caryophyllaied tapeworm, $C$. laticeps by Kennedy (1968) stated that tapeworm infection was more in females and confirmed that host hormone levels play a key role in the seasonality of tapeworm. It can be speculated that the testosterone immune-suppression, corticosteroid-based immune suppression and differences between the size and behaviour of the sexes may be reason behind the greater infection level in females than in males (Thomas, 2003).

The insignificant effect of sex on the $S$. esocinus shows that water quality and seasonality have more effect on the $A$. oreini than host sex. The feeding habits in female and male may mask the effect of sex on the intensity of $A$. oreini. Unequal distribution of parasitic infection between male and female have been reported in various studies and is still matter of debate among the parasitologists (Williams and Jones, 1994). 


\section{Effect of $A$. oreini on the health traits of fish}

The data from the present study indicate low GSI, which is the reflection of possible impacts of infection on the reproduction investment of fish. Comparatively high GSI at AI in S. niger both in infected and uninfected fish shows that low stress (here eutrophication) favours reproductive processes positively, whereas enhanced stress may have detrimental effect on reproductive index (Schreck, 2010). It has been reported that contaminants affect fish reproduction in several ways (Bieniarz et al. 1997). It is pertinent to mention that the GSI represents the measure of reproductive potential of fish. The GSI in the present investigation was low as compared with the previous studies, which are possibly due to deterioration of environmental factors of the lake over the past few decades. The significant decrease in reproductive trait across study sites and among different fish species suggests physical and biological transport of the contaminants in the lake.

The condition factor was significantly higher in uninfected hosts as compared with infected hosts in $S$. niger and $S$. curvifrons. The infection can decrease the immunity as well as growth of fish, which finally leads to decrease in health condition of a fish (Khan and Thulin, 1991; Poulin, 1992). Although, few reports have demonstrated the enhanced growth and greater condition coefficient due to parasitic burden (Megan and Bean, 2008; Ondrackova et al. 2009), majority are of the opinion that feeding habits and type of food may enhance the condition coefficient (Ondrackova et al. 2009; Polacik et al. 2009). It has been argued that healthy and well-conditioned fish have capability to acquire more infection because they accumulate more food and remain in those habits where exchange of parasite is possible (Thomas, 2003). Enhanced somatic growth in host can be also influenced by the release of factors through the stimulation host's immune and endrocrinological system (Thomas, 2003). The significant variation in slope (from the $\mathrm{L}-\mathrm{W}$ regression equation) of infected fishes shows that $A$. oreini infection and pollution have marked relationship with size and growth of fish and leads to stunted growth thereby having the negative effect on $\mathrm{L}-\mathrm{W}$ relationship (Esiest, 2013). Although literature shows that pollution and parasitism has an impact on $\mathrm{L}-\mathrm{W}$ relationship, there are other factors, including endocrine system, which regulate morphometric indices.

\section{CONCLUSIONS}

It can concluded from the results that infection pattern of tapeworm is determined by water quality, host species, copepod density and host biological feature. The results indicate that there exists a significant correlation between copepod density especially $C$. scutifer with the infection parameters, suggesting that the copepods in conjunction with lake features play an important role in determining the infection pattern of $A$. oreini. The results further reveal that the effect of altered water quality and parasite affect the health status of native fish as reflected by GSI and condition factor. This investigation will entice more research into additional aspects of different Caryophyllaeid tapeworms and will be useful for fisheries resource managers to prevent the damage posed by this caryophyllied infection on endemic fish fauna, which is currently under threat.

\section{ACKNOWLEDGEMENTS}

We acknowledge and appreciate the help and encouragement received from Professor Mohammad Aslam, Professor and Director, Research and Development, Central University of Kashmir. We also appreciate the kind support in the form laboratory facility from the former Director CORD, Professor Bashir Ahmad Ganai.

\section{FINANCIAL SUPPORT}

The first author, Ummer Rashid Zargar, received financial support from the Department of Science and Technology (SERB-DST), Govt. of India, in the form of a Fast Track Young Scientist Fellowship (Order No: YSS/2014/ 000845).

\section{REFERENCES}

American Public Health Association (2005). Standard Methods for the Examination of Water and Wastewater, 21st edn. American Public Health Association, The American Water Works Association and the Water Environment Federation, APHA-AWWA-WEF, Washington, DC, USA. Battish, S. K. (1992). Freshwater Zooplankton of India. Oxford \& IBH Publishing Co., New Delhi, India. 233 pp.

Beer, S. A. and German, S. M. (1993). Ecological prerequisites of worsening of the cercariosis situation in cities of Russia (Moscow Region as an example). Parazitologiya 27, 441-449.

Bertasso, A. and Avenant-Oldewage, A. (2005). Aspects of the ecology of the Asian tapeworm, B. acheilognathi Yamaguti, 1934 in the Yellowfish in Vaal Dam, South Africa. The Onderstepoort Fournal of Veterinary Research 72, 207-217.

Bhat, M. S. (2012). Population dynamics of genus Keratella in Dal Lake, Kashmir. M Phil thesis. University of Kashmir, Srinagar, India.

Bhat, S. A., Rather, S. A. and Pandit, A. K. (2001). Impact of effluents from Sheri- Kashmir Institute of Medical Sciences (SKIMS), Soura on Anchar Lake. Fournal of Research and Development 1, 30-37.

Bieniarz, K., Epler, P. and Sokolowska-Mikolajczyk, M. (1997). Reproduction of fish in conditions disadvantageously altered with the salts of zinc and copper. Archives of Polish Fisheries 5, 21-30.

Blanar, C. A., Kelly, R., Munkittrick, J., Houlahan, J., Deborah, L., MacLatchy, D. L. and Marcogliese, D. J. (2009). Pollution and parasitism in aquatic animals: a meta-analysis of effect size. Aquatic Toxicology 93, $18-28$.

Brouder, M. J. (1999). Relationship between length of roundtail chub and infection intensity of Asian fish tapeworm Bothriocephalus acheilognathi. Fournal of Aquatic Animal Health 11, 302-304.

Brouder, M. J. and Hoffnagle, T. L. (1997). Distribution and prevalence of the Asian fish tapeworm, Bothriocephalus acheilognathi, in the Colorado River and tributaries, Grand Canyon, Arizona, including two new host records. Fournal of Helminthological Society of Washington 64, 219-226.

Brunner, F. S. and Eizaguirre, C. (2016). Can environmental change affect host/parasite-mediated speciation? Zoology 119, 384-394. 
Brunner, F. S., Schmid-Hempel, P. and Barribeau, S. M. (2014) Protein-poor diet reduces host-specific immune gene expression in Bombus terrestris. Proceeding of Royal Society Biological Science 281, 20140128

Budria, A. and Candolin, U. (2014). How does human-induced environmental change influence host-parasite interactions? Parasitology 141, 462-474.

Budria, A. and Candolin, U. (2015). Human-induced eutrophication maintains high parasite prevalence in breeding three spine stickleback populations. Parasitology 142, 719-727.

Bush, A. O., Lafferty, K. D., Lotz, J. M. and Shostak, A. W. (1997). Parasitology meets ecology on its own terms: Margolis, et al. revisited. Fournal of Parasitology 83, 575-583.

De Vlaming, V., Grossman, G. and Chapman, F. (1982). On the use of the gonosomatic index. Comparative Biochemistry and Physiology 73A, 31

Dhar, R. L. and Peerzada, M. Y. (1989). Seasonal variation in the helminth parasites of common snow trout S.niger in Wular lake. National Symposium on Research Advances in Parasitology 15.

Edmondson, W. T., Anderson, G. C. and Peterson, D. R. (1956) Artificial eutrophication of lake Washington. Limnology and Oceanography 1, 47-53.

Ergens, R. and Lom, J. (1970). Causative Agents of Fish Diseases. Academia, Prague.

Esiest, U. L. P. (2013). Length-weight relationship and parasites of Chrysichthys nigrodigitatus in Cross River Estuary Itu local government area Akwa Ibom State, Nigeria. Basic Research Fournal of Agricultural Science and Review 2, 154-165.

Jan, N. A. and Das, S. M. (1970). Quantitative and qualitative studies on the food of eight fishes of Kashmir Valley. Ichthyology 10, 21-27.

Karvonen, A., Paukku, S., Valtonen, E. T. and Hudson, P. J. (2003) Transmission, infectivity and survival of Diplostomum spathaceum cercariae. Parasitology 127, 217-224.

Karvonen, A., Cheng, G. H. and Valtonen, E. T. (2005). Within-lake dynamics in the similarity of parasite assemblages of perch (Perca fluviatilis). Parasitology 131, 817-823.

Karvonen, A., Bjarni, K., Kristjansson, B. K., Skulason, S., Lanki, M. Rellstab, C. and Jokela, J. (2013). Water temperature, not fish morph, determines parasite infections of sympatric Icelandic three spine sticklebacks. Ecology and Evolution 3, 1507-1517.

Kennedy, C. R. (1968). Population biology of the cestode Caryophyllaeu laticeps (Pallas, 1781) in dace, Leuciscus leuciscus L. of the river Avon. Fournal of Parasitology 54, 538-543.

Kennedy, C. R. (1969). Seasonal incidence and development of the cestodes Caryophyllaeus laticeps (Pallas, 1781) in the river Avon Parasitology 59, 782-794.

Kennedy, C. R. (1994). The ecology of introductions. In Parasitic Diseases of Fish (ed. Pike, A. W. and Lewis, J. W.), pp. 189-209. Samara, Tresaith Khan, R. A. and Thulin, J. (1991). Influence of pollution on parasites of aquatic animals. Advanced Parasitology 30, 201-238.

Khanday, S. A., Yousuf, A. R., Reshi, Z. A., Rashid, I., Jehangir, A. and Romshoo, S. A. (2016). Management of Nymphoides peltatum using water level fluctuations in freshwater lakes of Kashmir Himalaya. Limnology 18, 219-231.

Knudsen, R., Curtis, M. A. and Kristoffersen, R. (2004). Aggregation of helminths: the role of feeding behavior of fish hosts. Fournal Parasitology 90, 1-7.

Koskivaara, M. (1992). Environmental factors affecting monogeneans parasitic on freshwater fishes. Parasitology Today 8, 339-342.

Kulakovskaya, O. P. (1964). Life cycles of Caryophyllaeidae (cestoda) in an invertebrate host. Zoologichesky Zhurnal 41, 86-92.

Le Cren, E. D. (1951). The length-weight relationship and seasonal cycle in gonadal weight and condition in the perch, Perca fluviatilus. Fournal of Animal Ecology 20, 201-219.

Mackereth, F. J. H., Heron, J. and Talling, J. F. (1978). Water analysis: some revised methods for limnologists. In Freshwater Biological Association, p. 120. Scientific Publication.

Malley, D. F., Chang, P. S. S., Findlay, D. L. and Linsey, G. A. (1988) Extreme participation of zooplankton community of a small Precambrian shield lake by the addition of nutrients. Verhandlungen des Internationalen Verein Limnologie 23, 2237-2247.

Marcogliese, D. J. and Esch, G. W. (1989a). Alterations in seasonal dynamics of Bothriocephalus acheilognathi in a north Carolina cooling reservoir in seven year period. Fournal of Parasitology 75, 378-382. Marcogliese, D. J. and Esch, G. W. (1989b). Experimental and Natural Infection of Planktonic and Benthic Copepods by the Asian Tapeworm, Bothriocephalus acheilognathi. Proceedings of Helminthological Society Washington 56, 151-155.
Marcogliese, D. J., Gendron, A. D. and Cone, D. K. (2009). Impact of municipal effluents and hyodrological regime on myxozoan parasite communities of fish. International Fournal for Parasitology 39, 1345-1351.

Margolis, L., Esch, G. W., Holmes, J. C., Kuris, A. M. and Schad, G. A. (1982). The use of ecological terms in parasitology (report Bush, et al. - Parasite Ecology and Terminnology 583 of an adhoc committee of the American Society of Parasitologists). Fournal of Parasitology 68, 131-133.

McKenzie, V. Z. and Townsend, A. R. (2007). Townsend Parasitic and infectious disease responses to changing global nutrient cycles. Ecohealth $\mathbf{4}$ 384-396.

Megan, G. and Bean, B. S. (2008). Occurrence and impact of the asian fish tapeworm Bothriocephalus acheilognathi in the Rio Grande (Rio Bravo Del Norte). Dissertation. Texas State University, Texas, USA.

Milbrink, G. (1975). Population biology of the cestode Caryophyllaeus laticeps (Pallas) in bream, Abramis brama (L.) and the feeding of fish on Oligochaetes. Annual Report from the Institute of Freshwater Research, Drottningholm 54, 36-51.

Molzen, B. (2005). Die Auswirkung des Befalls mit Plerocercoiden des Hechtbandwurms (Triaenophorus nodulosus (P).) auf den Flussbarsch (Perca fluviatilis L.) im Bodensee-Obersee. $\mathrm{PhD}$ thesis. LudwigMaximilians-Universität, Institut für Zoologie, Fischereibiologie und Fischkrankenheiten, München, Germany, 113 pp.

Morley, N. J., Costa, H. H. and Lewis, J. W. (2010). Effects of a chemically polluted discharge on the relationship between fecundity and parasitic infections in the chub (Leuciscus cephalus) from a river in southern England. Archives of Environment Contamination and Toxicology 58, 783-792.

Ondrackova, M., Davidova, M., Blazek, R., Gelnar, M. and Jurajda, P. (2009). The interaction between an introduced fish host and local parasite fauna: Neogobius kessleri in the middle Danube River. Parasitology Research 105, 201-208.

Oros, M., Hanzelová, V. and Scholz, T. (2004). The cestode Atractolytocestus huronensis (Caryophyllidea) continues to spread in Europe: new data on the helminth parasite of the common carp. Diseases of Aquatic Organisms 62, 115-119.

Palm, H. W. (2011). Fish parasites as biological indicators in a changing world: can we monitor environmental impact and climate change? In Progress in Parasitology (ed. Mehlhorn, H.), pp. 223-250. Parasitology Research Monographs 2, Springer-Verlag, Berlin, Heidelberg.

Pandit, A. K. and Yousuf, A. (2002). Trophic status of Kashmir Himalayan lakes as depicted by water chemistry. Fournal of Research and Development 2, 0972-5407.

Ping, X., Yan, Z., Man, D. and Takamura, N. (1996). Impact of different trophic levels on biodiversity of plankton community in lake Donghu. Fournal Acta Hydro Sinica 20, 30-37.

Polacik, M., Janac, M., Jurajda, P., Adamek, Z., Ondrackova, M. Trichkova, T. and Vassilev, M. (2009). Invasive gobies in the Danube: invasion success facilitated by availability and selection of superior food resources. Ecology of Freshwater Fish 8, 640-649.

Poulin, R. (1992). Toxic pollution and parasitism in freshwater fish Parasitology Today 8, 58-60.

Rückert, S., Hagen, W., Yuniar, A. T. and Palm, H. W. (2009) Metazoan parasites of fishes and their potential use as biological indicators in the Segara Anakan Lagoon, Indonesia. Regional and Environmental Change 9, 315-328

Sandland, G. J. and Goater, C. P. (2000). Development and intensity dependence of Ornithodiplostomum ptychocheilus metacercariae in fathead minnows (Pimephales promelas). Fournal of Parasitology $\mathbf{8 6}$ 1056-1060.

Schreck, C. B. (2010). Stress and fish reproduction: the roles of allostasis and hormesis. General and Comparative Endocrinology 165, 549-556.

Shah, H., Yousuf, A., Chisti, M. and Ahmad, F. (2013). Helminth communities of fish as ecological indicators of lake health. Parasitology 140, 352-360.

Siddig, A. A. H., Ellison, A. M., Ochs, A., Villar-Leemand, C. and Laub, M. K. (2016). How do ecologists select and use indicator species to monitor ecological change? Insights from 14 years of publication in Ecological Indicators. Ecological Indicators 60, 223-230.

Spellerberg, I. F. (2005). Monitoring Ecological Change. Cambridge University Press, Cambridge.

Tekin-Ozan, S., Kir, I. and Barlas, M. (2008). Helminth parasites of common carp (Cyprinus carpio L., 1758) in Beyșehir Lake and population dynamics related to month and host size. Turkish fournal of Fish and Aquatic Sciences 8, 201-205.

The Council for Scientific and Industrial Research (1974). An Analytical Guide. Part I. National Institute for Water Research, Pretoria, South Africa. 
Thomas, J. D. (2003). The ecology of fish parasites with particular reference to helminth parasites and their salmonid fish hosts in Welsh rivers: a review of some of the central questions. Advanced Parasitology 52, 1-154.

Valtonen, E. T., Marcogliese, D. J. and Julkunen, M. (2010).

Vertebrate diets derived from trophically transmitted fish parasites in the Bothnian Bay. Oecologia 162, 139-152.

Wanganeo, A. and Wanganeo, R. (2006). Variation in zooplankton population in two morphologically dissimilar rural lakes of Kashmir Himalayas. Proceedings of National Academy of Science, India 76, 222-239.

Weesner, F. M. (1968). General Zoological Microtechniques. The Williams and Wilkins Company, Baltimore, USA, p. 230.

Williams, H. and Jones, A. (1994). Parasitic Worms of Fish. Taylor and Francis Ltd, Bristol, London.
Zargar, U. R., Chishti, M. Z., Yousuf, A. R. and Ahmed, F. (2012a). Infection level of the Asian tapeworm (Bothriocephalus acheilognathi) in the cyprinid fish, Schizothorax niger, from Anchar Lake, relative to season, sex, length and condition factor. Parasitology Research 110, 427-435.

Zargar, U. R., Yousuf, A. R., Chishti, M. Z., Ahmed, F., Bashir, H. and

Ahmed, F. (2012b). Effects of water quality and trophic status on helminth infections in the cyprinid fish, Schizothorax niger Heckel, 1838 from three lakes in the Kashmir Himalayas. Fournal of Helminthology 86, $70-76$.

Zargar, U. R., Yousuf, A. R., Chishti, M. Z. and Ahmed, F. (2012c). Infection level of monogenean gill parasites, Diplozoon kashmirensis (Monogenea, Polyopisthocotylea) in Crucian Carp, Carassius carassius from lake ecosystems of altered water quality: what factors do have an impact on Diplozoon infection? Veterinary Parasitology 189, 218-226. 